\title{
ADMINISTRATION OF BONE MARROW DERIVED MESENCHYMAL STEM CELLS MODULATE TLR EXPRESSION DURING LIVER REGENERATION
}

\author{
Hande KOCAK ${ }^{1}$, Zeynep TOKCAER-KESKIN ${ }^{2}$, Burcu INSAL ${ }^{3}$, Ihsan GURSEL ${ }^{4}$, Kamil Can AKCALI ${ }^{5 *}$ \\ ${ }^{1}$ Department of Medical Biology and Genetics, Bilim University, Faculty of Medicine, İstanbul, TURKEY \\ ${ }^{2}$ Department of Molecular Biology and Genetics, Acıbadem University, İstanbul, TURKEY \\ ${ }^{3}$ Department of Anatomy, Ankara University, Faculty of Veterinary Medicine, Ankara, TURKEY \\ ${ }^{4}$ Biotherapeutic ODN Research Lab. Department of Molecular Biology and Genetics, İhsan Dogramaci Bilkent \\ University, Ankara, TURKEY \\ ${ }^{5}$ Department of Biophysics, Ankara University Faculty of Medicine, Ankara, TURKEY \\ *Corresponding author: ORCID ID: orcid.org/0000-0002-7816-6938, e-mail: akcali@ ankara.edu.tr
}

\section{Cite this article as:}

Kocak, H., Tokcaer-Keskin, Z., Insal, B., Gursal, I. \& Akcali, K.C. 2019. Administration of Bone Marrow Derived Mesenchymal Stem Cells Modulate TLR Expression During Liver Regeneration. Trakya Univ J Nat Sci, 20(Special Issue): S1-S10, DOI: 10.23902/trkjnat.505243

\begin{abstract}
Liver cell transplantation is a powerful alternative to orthotopic cell transplantation in the treatment of liver failures. Recently, considerable effort is being channeled to understand the nature and kinetics of directing stem cells to effectively accumulate at the regenerating liver site. Mesenchymal stem cells are one of the promising cell sources modulating liver regeneration process. The present was designed to study how mesenchymal stem cells might modulate liver immune behaviors by changing Toll-like receptor (TLR) expression and increase regenerative potential during liver regeneration in rats.

Normal and partially hepatectomized rats were treated with mesenchymal stem cells isolated and expanded from rat bone marrows. Accumulation of mesenchymal stem cells was confirmed by Real Time-Polymerase Chain Reaction (RT-PCR), Fluorescence-Activated Cell Sorting (FACS), and Immunofluorescence Staining (IFS). Student's t-test analysis was used to evaluate the significance of differences between sham and partially hepatectomized rat groups.

Our results showed that mesenchymal stem cells expressed several TLRs, and their accumulation during regeneration was depended on the timing of injury. Mesenchymal stem cells isolated from bone marrow of normal rats were observed at the injured liver 3 days after the injection. There were no labeled mesenchymal stem cells in the liver sections of the uninjured animals. Mesenchymal stem cell administration significantly altered the expression of TLR2, 3 and 9 while retaining their migration potential to regenerating liver.

Our findings implicated that mesenchymal stem cell administration during liver regeneration modulate the immune response through changing the expression of the TLRs in the remaining liver parts into which the cells are recruited or infused. This alteration may contribute to the regeneration process following partial hepatectomy.
\end{abstract}

Key words: Mesenchymal stem cell, TLR, homing, liver regeneration, rat.

Özet: Karaciğer hücresi nakli, karaciğer yetmezliğinde ortotopik hücre nakline güçlü bir alternatiftir. Son yıllarda, kök hücrelerin doğalarının, kinetiklerinin ve yenilenen karaciğer bölgesinde etkili bir şekilde toplanmalarının sağlanmasının anlaşılması için hatırı sayılır gayretler sarf edilmektedir. Mesenkimal kök hücreler karaciğer yenilenme sürecini modüle eden ümit verici hücre kaynaklarından bir tanesidir. Bu çalışma, mezenkimal kök hücrelerin sıçanlarda toll benzeri reseptör (TLR) ifadesini değiştirmek suretiyle karaciğer immün yanıtını nasıl etkileyebildiklerini ve karaciğer yenilenmesi esnasında yenilenme potansiyelini arttırabildiklerini belirlemek için gerçekleştirilmiştir.

Normal ve karaciğerleri kısmen çıkarılmış sıçanlar, sıçan kemik iliğinden elde edilip çoğaltılan mesenkimal kök hücreler ile muamele edilmişlerdir. Mesenkimal kök hücrelerin toplanması Eş Zamanlı Polimeraz Zincir Reaksiyonu (RT-PCR), Floresan Aktivite Hücre Ayırma (FACS), ve Immunfloresan Boyama (IFS) ile doğrulanmıştır. Sham ve karaciğeri kısmen alınmışs sıçan grupları arasındaki farklılığın istatistiki analizinde Student's t-testi kullanılmıştır.

Elde edilen sonuçlar mezenkimal kök hücrelerinde çeşitli TLR'lerin ifade edildiklerini ve bu hücrelerin yenilenme esnasında toplanmalarının meydana gelen hasarın zamanlamasına bağlı olduğunu göstermiştir. Normal sıçanların kemik iliğinden izole edilen mezenkimal kök hücreler hasarlı karaciğerde enjeksiyon sonrası 3. günde görülmüşlerdir. Hasarsız hayvanların karaciğer kesitlerinde işaretli bir mezenkimal kök hücre görülmemiştir. Mezenkimal kök hücre uygulaması TLR2, 3 ve 9'un ifadesinin anlamlı bir şekilde değiştirirken yenilenen karaciğere göç etme yeteneklerini devam ettirmişlerdir.

Sonuçlar, karaciğer yenilenmesi esnasında mezenkimal kök hücre uygulamasının, hücrelerin uygulandığı hasarsız karaciğer parçalarında TLR'lerin ifadelerini değiştirme yoluyla immün yanıtı modüle ettiğini ortaya koymaktadır. TLR ifadesindeki bu değişim kısmı hepatoktemi sonrası yenilenme sürecine katkı sağlayabilir niteliktedir. 


\section{Introduction}

Since its first development in the early 1960s (Starzl et al. 1963), orthotopic liver transplantation (OLT) has been considered as a gold standard in treatment of liver failure. However, other therapeutic strategies are also required due to the donor shortage. Despite its limiting factors such as cell viability, modest engraftment and limited tissue viability (Phillippe et al. 2008), liver cell transplantation (LCT) is one of the developing alternative solution with increasing success (Najimi \& Sokal 2005, Stéphenne et al. 2006). Stem cells are very potent candidates for LCT due to their plasticity (Verfaillie et al. 2002). Besides hematopoietic stem cells (HSCs) and adult liver stem/progenitor cells, mesenchymal stem cells (MSCs) are also used in liver cell therapy because of their hepatic differentiation potential (Phillippe et al. 2008).

MSCs are multipotent cells capable of self-renewal and differentiating into multiple lineages such as osteocytes, adipocytes, chondrocytes, myoblasts, hepatocytes and cardiomyocytes (Friedenstein et al. 1970, da Silva Meirelles et al. 2008, Tokcaer-Keskin et al. 2009). In addition to their hepatic potential, MSCs have two other important properties that make them critical for LCT. The first one is their preferential migration into the injured site. Migration of MSCs and their engraftment after the injury have been shown in several tissues including myocardium (Orlic et al. 2001) spinal cord (Hofstetter et al. 2002), brain (Kopen et al. 1999), kidney (Bussolati et al. 2008) and liver (Zhao et al. 2008). Secondly, MSCs can evade immune recognition and were implicated to suppress immune responses (Rasmusson 2006). Through multiple pathways, ex-vivo expanded MSCs were reported to down regulate a broad range of innate and adaptive immune cells including $\mathrm{T}$ cells, B cells, NK cells and antigen presenting cells (Stagg 2006) demonstrating their versatile immunoregulatory properties (Bartholomew et al. 2002, Aggrawal \& Pitteger 2005, Inoue et al. 2006). Although the mechanism is unclear yet, there seems to be several factors playing role in this immunoregulation. Pevsner-Fisher et al. (2007) showed that murine MSCs express several Toll-like receptors (TLRs) and in particular TLR2 was found to be important in differentiation potential of MSCs. It was also recently shown that human MSCs express several TLRs (Pervsner-Fischer et al. 2007, Tomchuck et al. 2008).

Cell surface or endosome-associated TLRs recognize a wide range of pathogen-associated molecular patterns (PAMPs) including carbohydrates, lipids, proteins and nucleic acids (Akira et al. 2006). Several immune cells such as macrophages, dendritic cells (DCs), B cells, specific types of $\mathrm{T}$ cells but also non-immune cells including fibroblasts and epithelial cells (Kumagai et al. 2008) signaling through TLRs were reported (Takeshita et al. 2004). In all cell types, expression of TLRs is modulated in response to pathogens, cytokines and environmental stress. While TLR1, 2, 4, 5 and 6 are expressed on the cell surface, TLR3, 7, 8 and 9 are found in intracellular compartments such as endosomes
(Arancibia et al. 2007). Ligands of the latter ones, mainly nucleic acids, are required to be internalized to endosomes for recognition.

The collaborative role of TLRs on MSCs' homing during liver regeneration has not been evaluated so far. By using a well established liver regeneration model of partially hepatectomized $(\mathrm{PH})$ rats, the present study was undertaken to investigate the interplay between MSCs and TLRs. Our findings implicated that MSC administration causes an increase in the expression of TLR2, 3 and 9 in the remaining liver and may facilitate MSC homing during liver regeneration.

\section{Materials and Methods}

\section{Animals and the experimental design}

Nine-weeks-old, 280-300 g, male Sprague-Dawley rats were obtained from the Experimental Animal Center of Bilkent University. The rats were housed in wire mesh cages under optimum laboratory conditions (temperature $22{ }^{\circ} \mathrm{C} \pm 2{ }^{\circ} \mathrm{C}$, humidity $50-55 \%$, light-dark period: $12 \mathrm{~h} / 12 \mathrm{~h}$ ) and daily fed with tap water and pellet foods, including \% 21 pure proteins. All experimental protocols were approved by the Local Animal Ethics Committee of Bilkent University. Our protocol complied with Bilkent University's guidelines on the humane care and use of laboratory animals.

Animals were divided randomly in 3 groups as isolation group of MSCs, normal group (sham; $\mathrm{SH}$ ) and partially hepatectomized (PH) group (Fig. 1). In the PH group, $70 \%$ of the liver mass was resected (Higgins et al. 1931), and in the normal group, identical surgical procedures were carried out without resection after injecting $30 \mathrm{mg} / \mathrm{kg}$ ketamine (Ketalar, Pfizer, Istanbul, Turkey). Three animals per group were used in the experiments. Operations were performed between 08:00 and 12:00 hours to minimize diurnal effects. For mRNA expression experiments, animals from both groups were killed by cervical dislocation at $2 \mathrm{~h}, 4 \mathrm{~h}, 12 \mathrm{~h}, 18 \mathrm{~h}$, and $24 \mathrm{~h}$ and after the operation. The remnant liver lobes were excised and immediately frozen in liquid nitrogen.

Isolation and culture labeling of MSCs and
administration to PH rats

MSCs were also obtained from male, nine-week-old, 280-300 g Sprague-Dawley rat bone marrow (BM) according to the methods described elsewhere (TokcaerKeskin et al. 2009). $2 \times 10^{6}$ of MSCs were treated with Chloromethylbenzamido-1, 1-dioctadecyl- 3,3,3',3'tetramethylindocarbocyanine perchlorate (CM-DiI) (Molecular Probes, USA) at a concentration of $5 \mu \mathrm{g} / \mathrm{mL}$ in $1 \mathrm{X}$ PBS. Four days after CM-DiI labeling, cells were removed and $1 \times 10^{6}$ cells $/ \mathrm{mL}$ labeled MSCs were injected to the normal rats to obtain $\mathrm{SH}$ and partially hepatectomized PH groups (Fig. 1). Animals were sacrificed by cervical dislocation at 1,3 , and 5 days following partial hepatectomy. The remnant liver lobes were excised and immediately frozen in liquid nitrogen. 


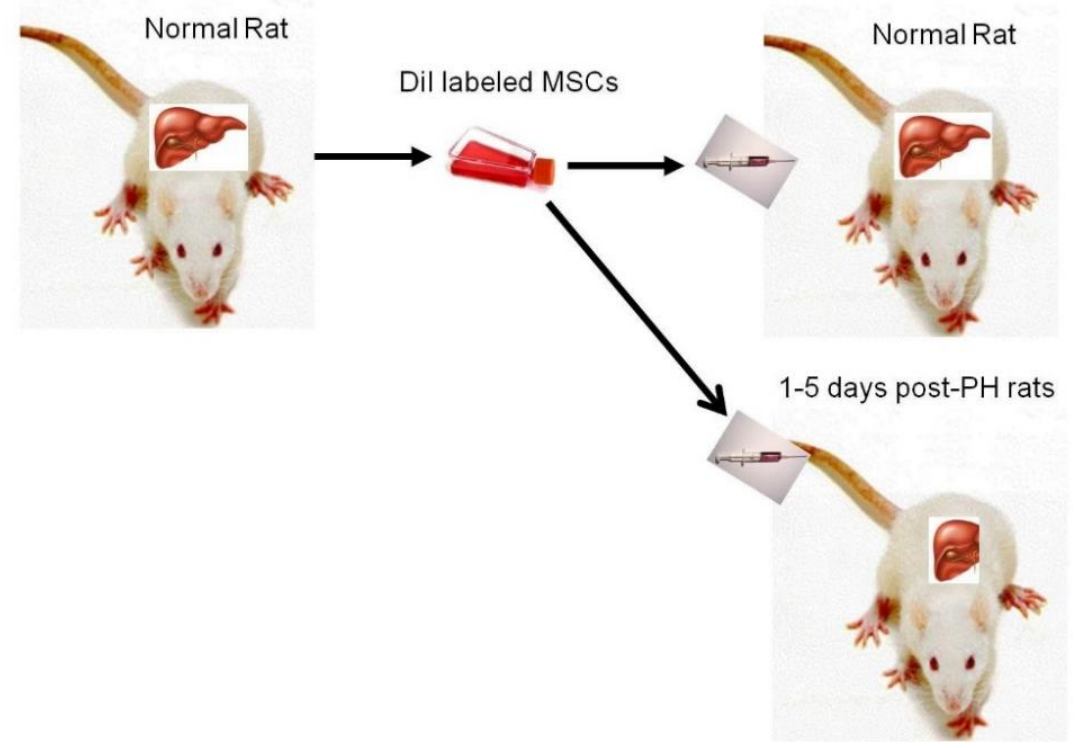

Fig. 1. MSCs were isolated and expanded from BM. CM-DiI labeled MSCs were injected into the normal and hepatectomized animals.

\section{Total RNA Isolation from Rat MSCs and Liver Tissues}

Total RNA from MSCs was isolated from the cell precipitate by using RNeasy Mini Kit (Qiagen, Hilden, Germany) and from liver tissues by using TriPure solution (Roche, Indiana, USA) according to the manufacturer's protocol. The cDNAs were synthesized with the DyNAmo cDNA synthesis kit (Finnzymes, Espoo, Finland) according to the manufacturer's protocol.

\section{$\underline{R T-P C R}$}

$R T-P C R$ conditions for CD11b, CD29, CD34, CD45, CD71, CD73, CD90, CD105, CD166 and GAPDH as the house keeping gene including corresponding primer sets are listed in Table 1. RT-PCR was done with DyNAmo ${ }^{\mathrm{TM}}$ HS SYBR ${ }^{\circledR}$ Green qPCR Kit (Finnzymes) according to the manufacturer's protocol.

Table 1. Primer sequences for RT-PCR, conditions and product sizes.

\begin{tabular}{|c|c|c|c|c|}
\hline $\begin{array}{l}\text { Gene } \\
\text { Acronyms }\end{array}$ & & Primer Sequences & Product Size (bp) & Cycle \# \\
\hline CD11b $b^{* a}$ & $\begin{array}{l}\text { Forward } \\
\text { Reverse }\end{array}$ & $\begin{array}{l}\text { GCTGGGAGATGTGAATGGAG } \\
\text { TGATGCTGGCTACTGATGCT }\end{array}$ & 113 & 30 \\
\hline $\mathrm{CD} 29 * * \mathrm{a}$ & $\begin{array}{l}\text { Forward } \\
\text { Reverse }\end{array}$ & $\begin{array}{l}\text { ACTTCAGACTTCCGCATTGG } \\
\text { GCTGCTGACCAACAAGTTCA }\end{array}$ & 190 & 26 \\
\hline $\mathrm{CD} 34 * * \mathrm{~b}$ & $\begin{array}{l}\text { Forward } \\
\text { Reverse }\end{array}$ & $\begin{array}{l}\text { TGTCTGCTCCTTGAATCT } \\
\text { CCTGTGGGACTCCAACT }\end{array}$ & 281 & 30 \\
\hline $\mathrm{CD} 45^{* * a}$ & $\begin{array}{l}\text { Forward } \\
\text { Reverse }\end{array}$ & $\begin{array}{l}\text { ATGTTATTGGGAGGGTGCAA } \\
\text { AAAATGTAACGCGCTTCAGG }\end{array}$ & 175 & 26 \\
\hline $\mathrm{CD} 71^{\$}$ & $\begin{array}{l}\text { Forward } \\
\text { Reverse }\end{array}$ & $\begin{array}{l}\text { ATGGTTCGTACAGCAGCAGA } \\
\text { CGAGCAGAATACAGCCATTG }\end{array}$ & 182 & 35 \\
\hline $\mathrm{CD} 3^{* \mathrm{a}}$ & $\begin{array}{l}\text { Forward } \\
\text { Reverse }\end{array}$ & $\begin{array}{l}\text { GAACTTGGGAGGGAGGAGAG } \\
\text { CATTGGCAGGAAGAGAGGAG }\end{array}$ & 282 & 30 \\
\hline $\mathrm{CD} 90^{* * \mathrm{~b}}$ & $\begin{array}{l}\text { Forward } \\
\text { Reverse }\end{array}$ & $\begin{array}{l}\text { CCAGTCATCAGCATCACTCT } \\
\text { AGCTTGTCTCTGATCACATT }\end{array}$ & 374 & 30 \\
\hline $\mathrm{CD} 105^{* \mathrm{a}}$ & $\begin{array}{l}\text { Forward } \\
\text { Reverse }\end{array}$ & $\begin{array}{l}\text { CGGGAGGTGTTTCTGGTCT } \\
\text { GTGTCTGGGTTCGTGGTTG }\end{array}$ & 331 & 30 \\
\hline CD166*a & $\begin{array}{l}\text { Forward } \\
\text { Reverse }\end{array}$ & $\begin{array}{l}\text { CTTTGTTCTGGGAGTGGCTG } \\
\text { GGTGTTGCCGTATGTGTTTG }\end{array}$ & 303 & 30 \\
\hline GAPDH $^{* a}$ & $\begin{array}{l}\text { Forward } \\
\text { Reverse }\end{array}$ & $\begin{array}{l}\text { AGACAGCCGCATCTTCTTGT } \\
\text { CTTGCCGTGGGTAGAGTCAT }\end{array}$ & 207 & 30 \\
\hline
\end{tabular}

* Initial Denaturation $95^{\circ} \mathrm{C} 10^{\prime}$, Denaturation $94^{\circ} \mathrm{C} 40^{\prime \prime}$, Extension $72^{\circ} \mathrm{C} 40^{\prime \prime}$, Final Extension $72^{\circ} \mathrm{C} 5^{\prime}$,

** Initial Denaturation $95^{\circ} \mathrm{C} 5^{\prime}$, Denaturation $94^{\circ} \mathrm{C} 30^{\prime \prime}$, Extension $72^{\circ} \mathrm{C} 30^{\prime \prime}$, Final Extension $72^{\circ} \mathrm{C} 10^{\prime}$,

a Annealing $60^{\circ} \mathrm{C} 30^{\prime \prime, ~ " ~}$ Annealing $55^{\circ} \mathrm{C} 30^{\prime \prime}$.

${ }^{\$}$ Initial Denaturation $95^{\circ} \mathrm{C} 5$ ', Denaturation $94^{\circ} \mathrm{C} 45^{\prime \prime}$, Annealing $66^{\circ} \mathrm{C} 60^{\prime \prime}$, Extension $72^{\circ} \mathrm{C} 45^{\prime \prime}$, Final Extension $72^{\circ} \mathrm{C} 10^{\prime}$. 


\section{$\underline{\text { Real-Time RT-PCR Studies }}$}

Rat TLR primer sequences were adopted from Hubert et al. (2006) and CYC was used as the house keeping gene. Efficiency of all primers were tested, standard curves were derived and $\mathrm{E}$ values were calculated (Table 2). The $\mathrm{C} t$ values of the $i$ ) normal liver and $\mathrm{PH}$ groups (post PH at 2, 4, 12, 18 and 24 hours) for TLR genes and $C Y C$ and ii) $\mathrm{PH}$ groups (normal liver vs. 1 and 3 days post$\mathrm{PH}$ ) and MSC-administered $\mathrm{PH}$ groups (normal liver vs. 1 and 3 days post-PH) for $T L R 2,3$, and 9 genes and $C Y C$ were calculated. By using normalized $\mathrm{C} t$ values, $\Delta C t$ $\left(\Delta C t_{T L R} / \Delta C t_{C Y C}\right)$ for each $T L R$ at indicated time was calculated. Fold changes in the expression of the tested TLR genes werecalculated by using the $2^{-(\Delta \mathrm{CtPH}-\Delta \mathrm{CtNL})}$ formula. Real-time RT-PCR reactions followed by a melting curve analysis were carried out in Cycler $^{\mathrm{TM}}$ (BioRad, Hercules, CA, USA). Q-RT-PCR conditions for all investigated genes have an initial denaturation $95^{\circ} \mathrm{C}, 10$ minutes followed by 40 cycles of denaturation for 15 seconds at $95^{\circ} \mathrm{C}$, annealing for 60 seconds at $60^{\circ} \mathrm{C}$, followed by extension of 60 seconds at $60^{\circ} \mathrm{C}$. Final extension was set at $72^{\circ} \mathrm{C}$ for 5 minutes. Samples from $\mathrm{PH}$ and $\mathrm{SH}$ groups obtained at different time points were detected in duplicates, and readings from each sample and its internal control were used to calculate gene expression level.

\section{Cell Surface Marker Staining and Analyses by FACS}

Staining protocol was slightly modified from previously published protocol (Gursel et al. 2006). Rat specific antibodies against CD90-FITC (Santa Cruz
Biotechnology, CA, USA), and CD45-PE/Cy5 (Abcam, Cambridge, UK) with isotype controls were used to characterize MSCs. The cells were incubated in dark for 30 minutes and were washed twice, resuspended in $500 \mu \mathrm{l}$ PBS-BSA-Na azide and analyzed in FACSCalibur (BD, USA). FACS dot plots were assessed by Cell Quest Pro software.

\section{Immunofluorescence Staining (IFS)}

$5 \mu \mathrm{m}$ sections of frozen liver tissues were fixed in $4 \%$ paraformaldehyde for 30 minutes and were immersed in 3 $\% \mathrm{H}_{2} \mathrm{O}_{2}$ (in methanol v/v) for 30 minutes. After washing with phosphate buffered saline $\mathrm{pH}$ : 7.2-7.4 (PBS), the specimen was blocked with $2 \%$ bovine serum albumin (BSA) for 1 hour at room temperature (RT) in a humid chamber. Sections were then incubated with anti-FLT3 (Santa Cruz Biotechnology) and anti-CD90 (Chemicon, Temecula, Canada) antibodies at RT for one hour at a dilution of $1 / 50$ and $1 / 500$ in $1 \%$ BSA, respectively. The tissues were incubated with FITC-labeled anti-mouse IgG (Sigma, St. Louis, MO, USA) and FITC-labeled anti-rabbit IgG (Sigma) for CD90 and FLT3, respectively. After incubating in dark for 1 hour at RT, the specimens were mounted using UltraCruz TM (Santa Cruz) medium with DAPI and examined under fluorescence microscope.

\section{Statistical Analysis}

Statistical significance between $\mathrm{PH}$ and $\mathrm{SH}$ groups was determined using the Student's $t$-test analysis. $P$ value $<0.05$ was considered to be statistically significant.

Table 2. The sequences of different rat TLR primers (adopted from Hubert et al. 2006) and efficiency values of the primer sets (E value).

\begin{tabular}{|l|l|l|c|c|}
\hline $\begin{array}{l}\text { Gene } \\
\text { Acronyms }\end{array}$ & \multicolumn{1}{|c|}{ Primer Sequences } & Product Size (bp) & E value \\
\hline TLR1 & $\begin{array}{l}\text { Forward } \\
\text { Reverse }\end{array}$ & $\begin{array}{l}\text { CAGCAGCCTCAAGCATGTCT } \\
\text { CAGCCCTAAGACAACAATACAATAGAAGA }\end{array}$ & 82 & 1.94 \\
\hline TLR2 & $\begin{array}{l}\text { Forward } \\
\text { Reverse }\end{array}$ & $\begin{array}{l}\text { CTCCTGTGAACTCCTGTCCTT } \\
\text { AGCTGTCTGGCCAGTCAAC }\end{array}$ & 74 & 1.94 \\
\hline TLR3 & $\begin{array}{l}\text { Forward } \\
\text { Reverse }\end{array}$ & $\begin{array}{l}\text { GCACTGTGAGATACAACGTAGCT } \\
\text { GAAGGTCATCAGGTATGTGTGTCA }\end{array}$ & 66 & 1.98 \\
\hline TLR4 & $\begin{array}{l}\text { Forward } \\
\text { Reverse }\end{array}$ & $\begin{array}{l}\text { TGCTACAGTTCATCTGGGTTTCTG } \\
\text { CTGTGAGGTCGTTGAGGTTAGAAG }\end{array}$ & 78 & 1.88 \\
\hline TLR5 & $\begin{array}{l}\text { Forward } \\
\text { Reverse }\end{array}$ & $\begin{array}{l}\text { GGGCAGCAGAAAGACGGTAT } \\
\text { CAGGCACCAGCCATCCTTAA }\end{array}$ & 61 & 1.86 \\
\hline TLR6 & $\begin{array}{l}\text { Forward } \\
\text { Reverse }\end{array}$ & $\begin{array}{l}\text { AGAACCTTACTCATGTCCCAAAAGAC } \\
\text { AGATCAGATATGGAGTTTTGAGACAGACT }\end{array}$ & 79 & 2.99 \\
\hline TLR7 & $\begin{array}{l}\text { Forward } \\
\text { Reverse }\end{array}$ & $\begin{array}{l}\text { GTTTTACGTCTACACAGTAACTCTCTTCA } \\
\text { TTCCTGGAGGTTGCTCATGTTTT }\end{array}$ & 75 & 2.00 \\
\hline TLR8 & $\begin{array}{l}\text { Forward } \\
\text { Reverse }\end{array}$ & $\begin{array}{l}\text { GGCTTCGGCAGAGGATCT } \\
\text { GCCAAAACAAGTTTCCGCTTTG }\end{array}$ & 75 & 2.00 \\
\hline TLR9 & $\begin{array}{l}\text { Forward } \\
\text { Reverse }\end{array}$ & $\begin{array}{l}\text { CCGAAGACCTAGCCAACCT } \\
\text { TGATCACAGCGACGGCAATT }\end{array}$ & 70 & 1.90 \\
\hline TLR10 & $\begin{array}{l}\text { Forward } \\
\text { Reverse }\end{array}$ & $\begin{array}{l}\text { FTCCAACATGGCTTTAAGGAAGGT } \\
\text { TGGAATTGATAGAGGAGGTTGTAGGA } \\
\text { Reverse }\end{array}$ & $\begin{array}{l}\text { GGGAGGGTGAAAGAAGGCAT } \\
\text { GAGAGCAGAGATTACAGGGT }\end{array}$ & 90 \\
\hline
\end{tabular}




\section{Results}

\section{Characterization of MSC by PCR and by FACS}

We first isolated MSCs from rat bone marrow. Consistent with previous observations by us and others (Tokcaer-Keskin et al. 2010, Mangi et al. 2003, Pittenger et al. 1999), the cells were positive for MCS markers such as CD90, CD71, CD73, CD29, CD105 and CD166 and negative for hematopoietic cell lineage markers such as CD11b, CD34 and CD45 at the transcript level (Fig. 2A). We further confirmed that these MSCs were positive for CD90 (84.5 $\pm 7.2 \%$ of total population, MFI: $334.5 \pm 150.3$ ) and negative for CD45 $(96.6 \pm 1.2 \%$ of total population, MFI: $10.4 \pm 0.5)$ by FACS (Fig. 2B). Then we investigated the expression of TLRs in MSCs (Fig. 2C). Our results showed that rat MSCs express TLR1, 2, 3, 4, 6, and 9 mRNA (Fig. 2C).

\section{Homing of MSCs in Partially Hepatectomized Rats}

We partially hepatectomized rats and then injected CM-DiI labeled MSCs isolated from normal animal's bone marrow (Fig. 3). No injection of MSCs was our negative group (Fig. 3A-B). CM-DiI labeled MSCs were administered to the animal that did not undergo PH (Fig. $3 \mathrm{C}-\mathrm{D}$ ), to 1 day post-PH group (Fig. 3E-F), to 3 days post$\mathrm{PH}$ group (Fig. 3G-H) and to 5 days post-PH group (Fig. 3I-J) through their tail vein. Three days after MSC administration, animals were sacrificed. Fluorescence microscopy studies revealed that a thin layer of CM-DiI positive MSCs were localized at the outermost border of the $\mathrm{PH}$ liver sections only in 3 days post-PH animals (Fig. $3 \mathrm{H})$. Untreated, 1 day and 5 days post-PH animals gave no detectable CM-DiI specific signal (Fig. 3D, 3F and 3J respectively). As expected, no staining in the liver sections was observed when MSCs were not injected (Fig. 3B). This data implicated that MSCs were accumulating in the liver upon liver injury in a specific timing (Fig. 3H).

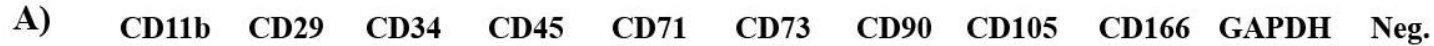

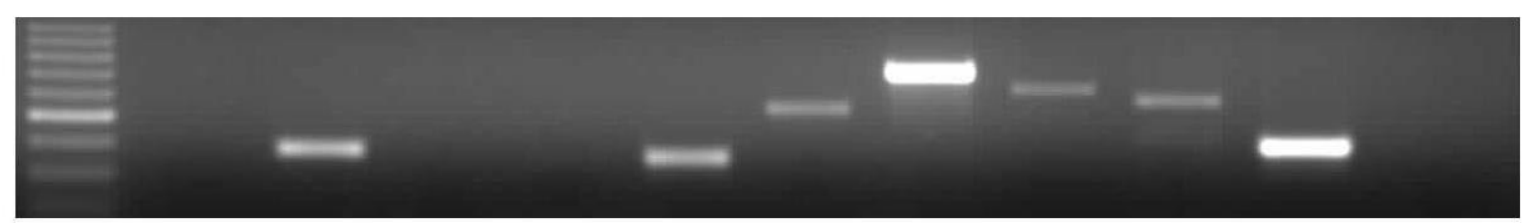

\section{B)}
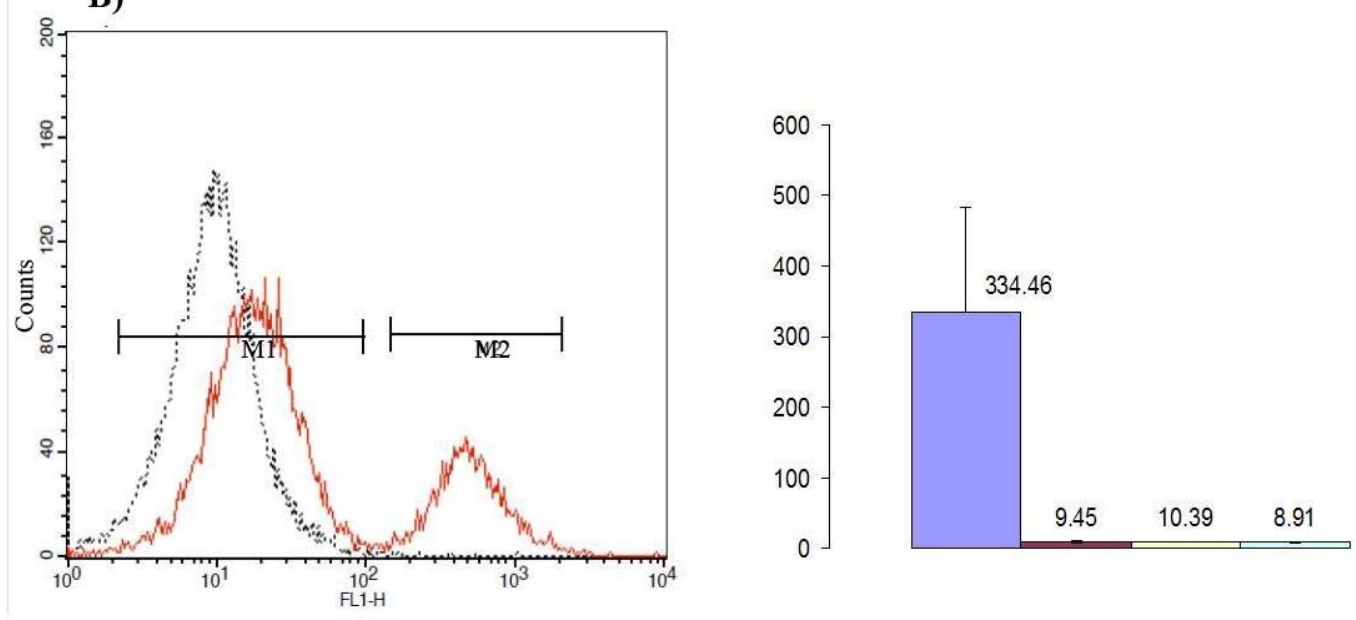

C)

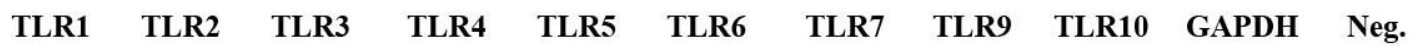

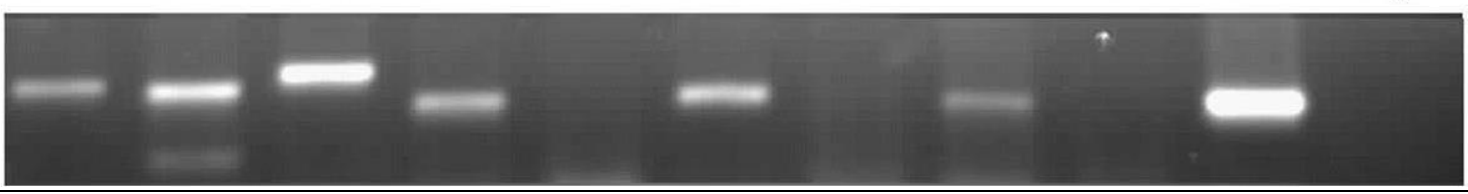

Fig. 2. Characterization and TLR expression profile of MSCs. A) Gel picture showing MSC-specific positive (CD 29, CD71, CD73, CD90, CD105 and CD 106) and negative (CD 11b, CD34 and CD45) marker transcripts, B) Quantification of CD90 and CD45 proteins expressed by MSCs (MSCs were positive for CD90 (84.5 $7.2 \%$ of total population, MFI: $334.5 \pm 150.3$ ) and negative for CD45 (96.6 $\pm 1.2 \%$ of total population, MFI: $10.4 \pm 0.5)$ ) by FACS (at day14), C) PCR gel image showing the MSC expression levels of rat (TLR1, 2, 3, 4, 6, and 9 mRNA) amongst TLR1-10. 


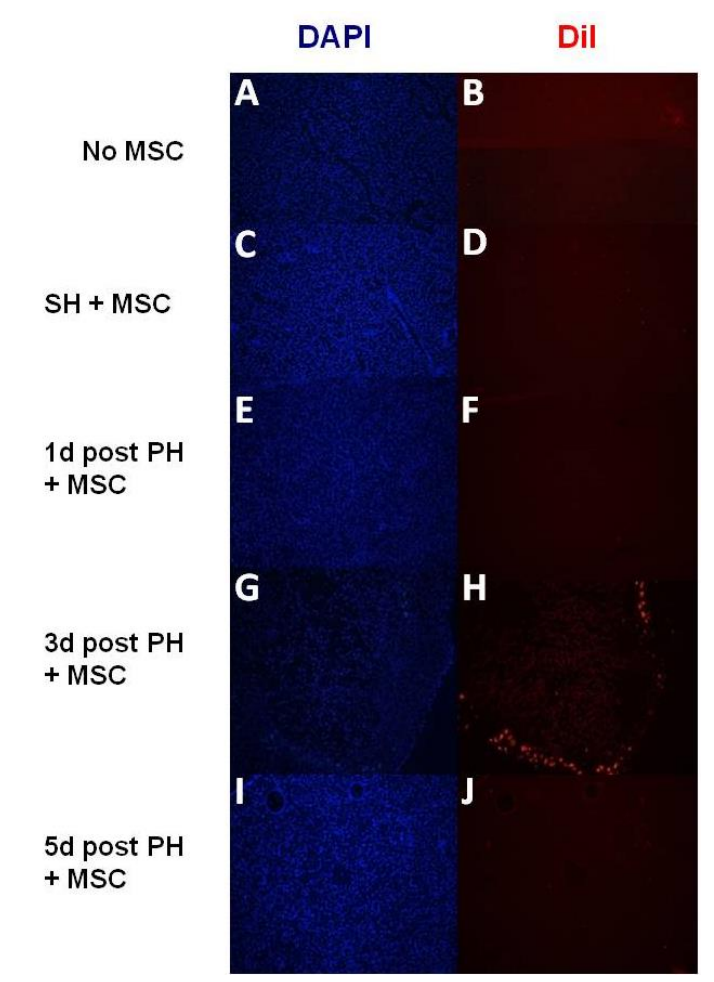

Fig. 3. Fluorescence photomicrographs of the liver sections injected with CM-DiI labeled MSCs. CM-DiI labeled MSCs were injected into $\mathrm{SH}(\mathrm{C}, \mathrm{D}), 1$ day post-PH (E, F) 3 days post$\mathrm{PH}(\mathrm{G}, \mathrm{H})$ and 5 days post-PH $(\mathrm{I}, \mathrm{J})$ rats. Background staining from untreated and no MSC received liver sections (A, B). Thin layer of CM-DiI positive MSCs were localized at the outermost border of the $\mathrm{PH}$ liver sections only in 3 days post-PH animals (H). Arrows: CM-DiI labeled MSCs. Magnification: 20X.

\section{CD90 Expression in Partially Hepatectomized Livers}

After observing the presence of CM-DiI positive MSCs in PH liver, contribution of resident MSCs mediating liver regeneration process in the injured niche was examined. We performed immune staining for CD90 to investigate the recruitment of resident MSCs adjacent to CM-DiI labeled allogeneic MSCs (Fig. 4). The presence of the cells was shown by DAPI staining (Fig. 4A). The accumulation of the injected MSCs was evident by CM-DiI staining (Fig. 4B). Several resident CD90 positive MSCs (Fig. 4C) were present and scattered around CM-DiI-labeled MSCs as evidenced by merging of CM-DiI and FITC-CD90 (Fig. 4D) in the liver section of the 3 days post-PH rats. Consistent with earlier observations, no specific CD90 staining was observed for normal, 1 day and 5 days post-PH rats (data not shown).

\section{FLT3 Expression in Partially Hepatectomized Livers}

Oval cells are known to play pivotal role during progenitor-dependent liver regeneration and they express FLT3 on their cell surface (Alison 1998). Immunofluorescent staining against FLT3 was performed to check the existence of hepatic oval cells in the hepatectomized liver sections after the administration of CM-DiI-labeled MSCs (Fig. 5). FLT3 positivity was observed in the vicinity of CM-DiI positive MSCs in the liver of 3 days post-PH rats (Fig. 5A-D).

\section{TLR Expression Following MSC Infusion During Liver} Regeneration

In order to understand the contribution of TLRs during homing process of MSCs in liver regeneration, the changes of the expression patterns of several TLRs from normal and hepatectomized livers over $24 \mathrm{~h}$ by real-time RT-PCR were examined. From $\mathrm{C} t$ values, fold change in expression for each TLR was plotted (Fig. 6A-F). From these plots, it was apparent that specifically four genes (TLR2, TLR3, TLR5 and TLR 9) remained unaltered (i.e. expression levels $\sim 1.0$ ) over the course of first 24 h postPH compared to normal liver (Fig. 6A, 6B, 6D and 6F). Before investigating further, we omitted the potential contribution of TLR 5 due to the fact that MSCs do not express this mRNA (Fig. 2C).
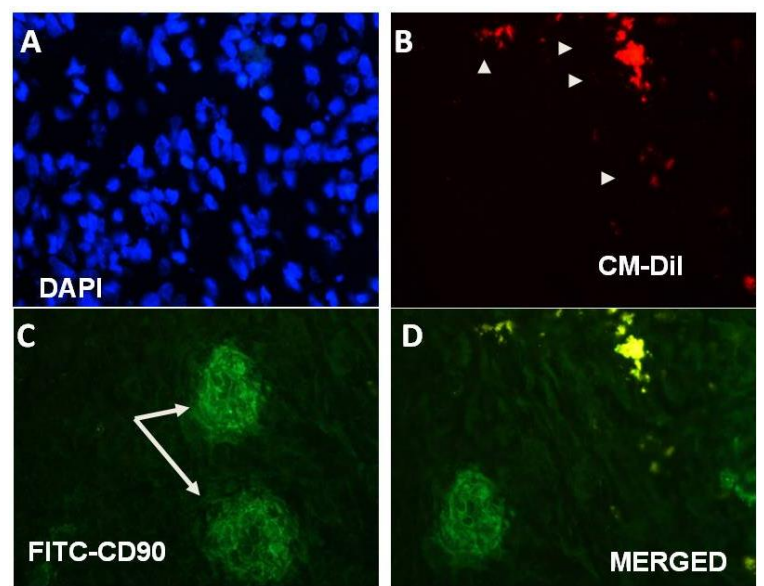

Fig. 4. Immunofluorescence photomicrographs showing CD90 expression. Sections were from 3 days post PH liver that had been injected with CM-DiI labeled MSCs revealing the contribution of resident MSCs mediating liver regeneration process in the injured niche. (A) DAPI, (B) CM-DiI (C) CD90FITC (D) merged. Arrows: CD90+ areas. Arrow Heads: CM-DiI positive areas. Magnification: $20 \mathrm{X}$.
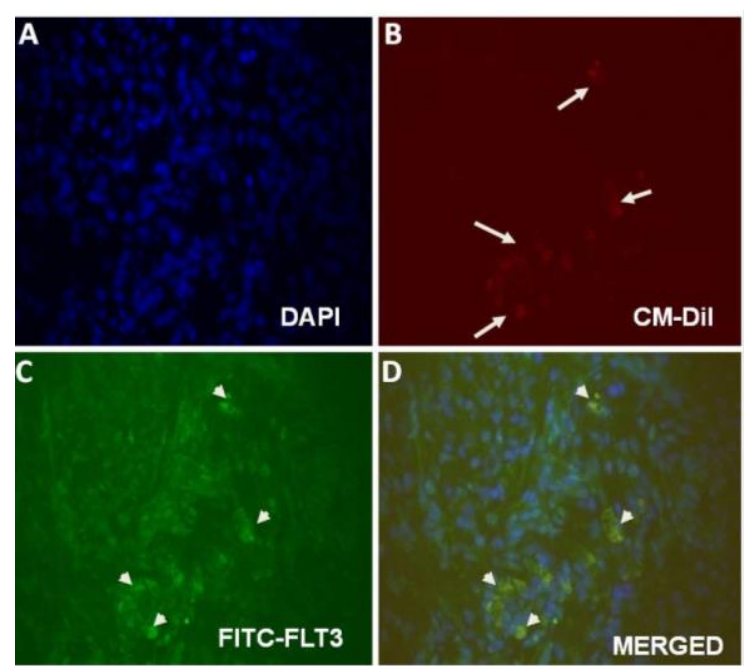

Fig. 5. Immunofluorescence photomicrograph showing FLT3 expression. Sections were from 3 days post PH liver that had been injected with CM-DiI labeled MSCs revealing the existence of hepatic oval cells in the hepatectomized liver sections. (A) DAPI (B) CM-DiI (C) FLT3-FITC and (D) Merged. Arrows: CM-DiI and arrow heads: FITC-FLT3 positive areas. Magnification: 20X. 
A

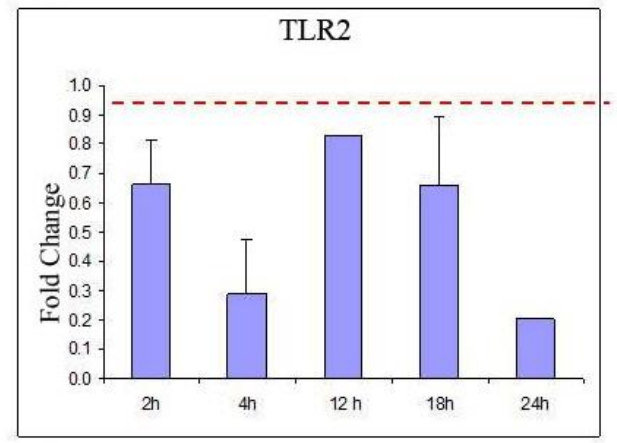

$\mathrm{C}$

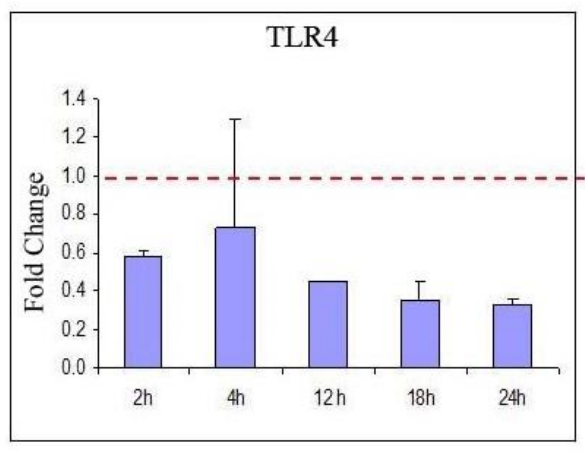

$\mathrm{E}$

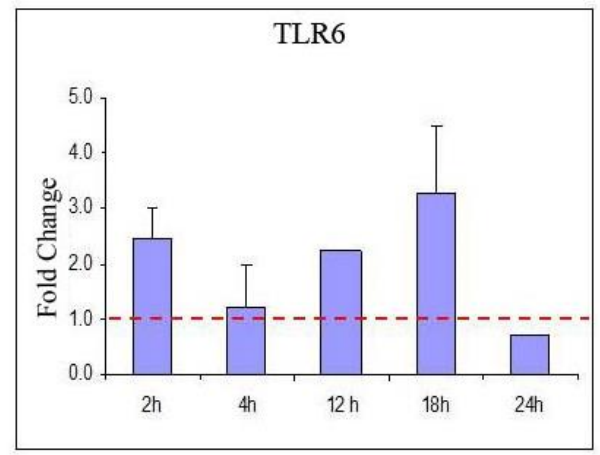

B

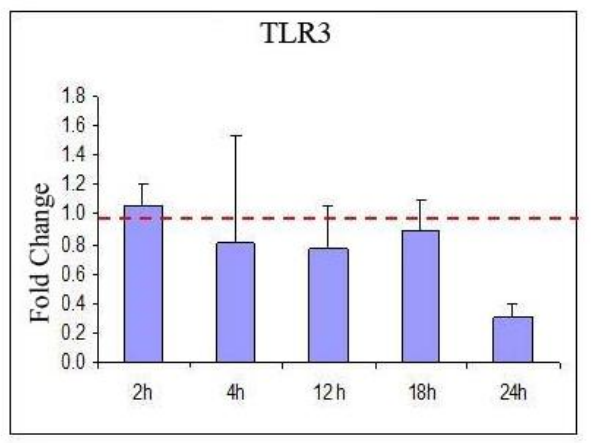

$\mathrm{D}$

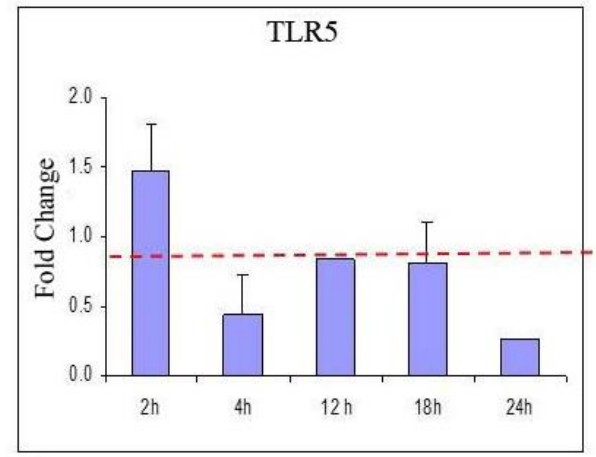

$\mathrm{F}$

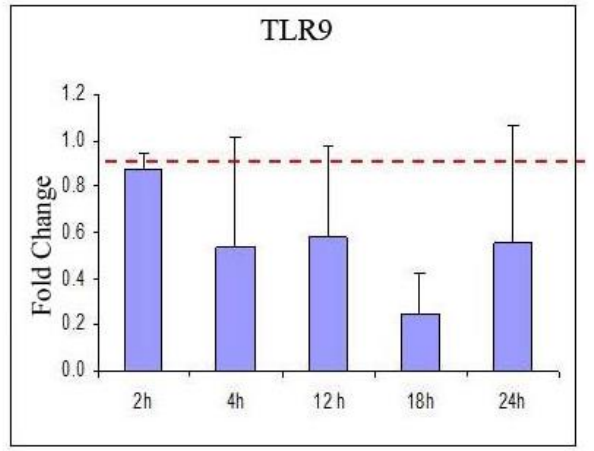

Fig. 6. qRT-PCR profiles showing time course fold change of (A) TLR2, (B) TLR3, (C) TLR4, (D) TLR5, (E) TLR6 and (F) TLR9 gene transcript levels following PH over $24 \mathrm{~h}$. TLR2, TLR 3, TLR 5 and TLR 9 remained unaltered over the course of first $24 \mathrm{~h}$ post$\mathrm{PH}$ compared to normal liver.

Next, we checked changes in TLR expression level upon MSC administration during liver regeneration. To our knowledge, no study has attempted to delineate the changes in TLR expression and MSC accumulation following injury. In order to differentiate whether TLR2, TLR3 and TLR9 are involved in the homing of administered MSCs to the injured site, the time-course fold change in their transcript levels was investigated. Our results revealed that TLR2, TLR3 and TLR9 mRNA expression levels increased in liver samples of partially hepatectomized rats that received labeled MSC in comparison to those animals that did not have any MSC treatment (Table 3). Following MSC injection, TLR2 and TLR9 mRNA levels were significantly higher than TLR3 in regenerating liver (ca. 7 fold for TLR2 and 9 vs $\sim 2$ fold for TLR3).
Table 3. Fold change in TLR2, TLR 3 and TLR9 expression of PH animals before and after MSC administration from normal rats.

\begin{tabular}{lccc}
\hline \hline Rx groups & TLR2 & TLR3 & TLR9 \\
\hline \hline Mock + MSC & $1.9 \pm 0.3$ & $2.2 \pm 0.5$ & $2.8 \pm 0.1$ \\
PH (1d) & $1.3 \pm 0.2$ & $0.3 \pm 0.1$ & $1.6 \pm 0.6$ \\
PH (1d) + MSC & $5.7 \pm 1.1$ & $1.7 \pm 0.4$ & $3.9 \pm 0.7$ \\
PH (3d) & $1.3 \pm 0.3$ & $0.6 \pm 0.2$ & $1.2 \pm 0.4$ \\
PH (3d) + MSC & $7.7 \pm 0.9$ & $2.1 \pm 0.1$ & $4.3 \pm 0.5$ \\
\hline \hline
\end{tabular}

\section{Discussion}

In this study, we aimed to understand the immune response of liver upon BM derived MSCs infusion through changes in TLR expression of remaining liver and delineate their contribution to regeneration process. 
There are several heartening therapeutical applications of MSCs in osteogenesis imperfecta, hematopoietic recovery, bone tissue regeneration, cardiovascular repair, spinal cord injury, coronary artery disease and also in several organ failures such as lung fibrosis in animal models (Horwitz et al. 1999, Koc et al. 2000, Petite et al. 2000, Minguell et al. 2001, Matty 2008). Although Popp et al. (2007) reported that multipotent mesenchymal stromal cells do not differentiate into hepatocytes in vivo when transplanted in regenerative conditions, Lee et al. (2004) showed that bone marrow-derived MCS from human differentiate into functional hepatocyte-like cells under defined conditions pointing out the potential for clinical relevance. Moreover, recent findings suggested that these cells can effectively rescue experimental liver failure (upon $\mathrm{CCl}_{4}$ administration) and contribute to liver regeneration. Collectively, accumulating data implicated that MSCs are suitable cell-based tools as an alternative therapy to organ transplantation for the treatment of liver diseases (Kuo et al. 2008). The signals driving MSCs to the site of injury during healing is not convincingly resolved and there are conflicting reports describing the physiologic roles of TLR expression on isolated/generated MSCs. These controversies prompted us to investigate in detail the relevance between migration of MSC to and contribution of TLRs to this process using hepatectomized rat as a model in experimental liver regeneration.

In order to chase homing of MSCs in liver after PH, CM-DiI labeled MSCs from normal rats were administrated into the 1, 3 and 5 post-PH rats. Our results revealed that only in 3 day post-PH rat, MSCs were localized in the liver (Fig. $3 \mathrm{H}$ ).

Next, we asked the question of whether endogenous MSCs also show the similar homing pattern to allogeneic MSCs during liver regeneration in terms of timing and localization. Our immunoflourescein data for CD90 staining in the liver sections revealed that the time of the appearance of endogenous MSCs are synchronous to that of exogenously localized allogeneic MSCs. These cell types were co-localized at the liver regeneration site 3 days post-PH (Fig. 4C and 4D). This suggested that either localized administered MSCs induced further accumulation of the syngeneic MSCs, or the accumulation process of the resident MSCs reached to a plateau, and furthermore initiated injected MSCs to localize at the injury site. Further studies to clarify these alternatives are required.

Oval cells are playing pivotal role in progenitordependent liver regeneration and are known to express specific proteins at their surfaces (Allison 1998). Among these, FLT3 is one of the candidate proteins (Agnes et al. 1994). FLT3 is a receptor tyrosine kinase (RTK) and a well-known hematopoietic stem cell marker (Agnes et al. 1994). We previously showed the expression of FLT3 both at mRNA and protein level during progenitor celldependent liver regeneration (Aydin et al. 2007). In this study, FLT3 expression was observed only when MSCs administrated into 3 days PH rats in the vicinity of labeled MSCs. Expression of FLT3 around this location suggests the onset of progenitor-dependent liver regeneration. However, we do not know the factors that regulate the specific pattern of MSC localization in the regenerated liver. Future studies to elucidate these factors (such as chemo attractant molecules) are expected to better understand liver regeneration process and provide very useful information for possible therapies.

Faust et al. (2006) proposed that three major pathways may regulate the circuitry required for liver regeneration. These are i) cytokine, ii) growth factor and iii) metabolic networks linking liver function to cell growth and proliferation. It is proposed that the innate immune system plays an important role in the initiation of liver regeneration after partial hepatectomy (Hritz et al. 2008). In particular, IL6 and TNF $\alpha$ production by Kupffer cells are found to be required for initiation of liver regeneration after $\mathrm{PH}$, although the activation processes are still unknown. TLRs are important upstream elements of proinflammatory cytokine networks. Watanabe et al. (2007) showed that IL6 and TNF $\alpha$ production decrease significantly leading to defective liver regeneration in

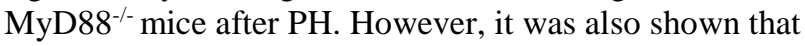
TLR 2, 4 and 9 are not essential for NF- $\mathrm{BB}$ activation and IL6 secretion (Seki et al. 2005, Campbell et al. 2006). The latter observation is particularly surprising since entericderived LPS (ligand of TLR4) was shown as the stimulating agent for proinflammatory cytokine production at the start of liver regeneration (Cornell 1985, Cornell 1990, Shiratori et al. 1996). Therefore, we decided to investigate the mRNA expression of several TLR genes in $0 \mathrm{~h}, 2 \mathrm{~h}, 4 \mathrm{~h}, 12 \mathrm{~h}, 18 \mathrm{~h}$ and $24 \mathrm{~h}$ after $\mathrm{PH}$ (Fig. 6). Our results revealed that induction in the expression of TLR 2, 3, 5 and 9 remain nearly unchanged during this testing period compared to the expression levels of normal animals at $0 \mathrm{~h}$.

We hypothesized that the mechanism of MSC homing to injury site may be due to TLR expression of the organ in which injury occurs, and investigated the relationship between TLR expression profiles of hepatectomized liver upon MSC infusion. It was shown that TLR stimulation on human MSC drives their migration in vitro (Tomchuck et al. 2008). In the light of this data, one can hypothesize that certain TLR expression at the injured tissue/organ may be critical for the MSC migration leading to regenerative process. Our results strongly suggest the involvement of TLR 2, 3 and 9 due to following observations: i) their expressions are relatively unchanged over the period of 24 hours after $\mathrm{PH}$ of the host animals in the absence of MSC infusion (Fig. 6), ii) mRNA expression levels of TLR 2, 3 and 9 are increased in MSCadministrated 1day $\mathrm{PH}$ and 3days $\mathrm{PH}$ rat liver samples in comparison to that of $\mathrm{PH}$ animals that had no MSC injection (Table 1). Thus, the injected MSCs induced the alteration of TLR 2, 3 and 9 levels in the remaining liver during regeneration. 
In conclusion, our data suggested that the driving force of MSC homing is not dependent on TLR expression of MSCs, rather TLR upregulation in the micro environment of the injured liver in part may dictate MSC homing. Thus, immune response mediated by TLR signaling during regeneration process is critical for MSC homing.

\section{References}

1. Aggrawal, S. \& Pitteger, M.F. 2005. Human mesenchymal stem cells modulate allogeneic immune cell responses. Blood, 105(4): 1815-1822.

2. Agnès, F., Shamoon, B., Dina, C., Rosnet, O., Birnbaum, D. \& Galibert, F. 1994. Genomic structure of the downstream part of the human FLT3 gene: exon/intron structure conservation among genes encoding receptor tyrosine kinases (RTK) of subclass III. Gene, 145(2): 283288.

3. Akira, S., Uematsu, S. \& Takeuchi, O. 2006. Pathogen recognition and innate immunity. Cell, 124: 783-801.

4. Alison, M. 1998. Liver stem cells: a two compartment system. Current Opinion in Cell Biology, 10(6): 710-715.

5. Arancibia, S.A., Beltrán, C.J., Aguirre, I.M., Silva, P., Peralta, A.L., Malinarich, F. \& Hermoso, M.A. 2007. Tolllike receptors are key participants in innate immune responses. Biological Research, 40: 97-112.

6. Aydin, I.T., Dalgic, A., Konu, O. \& Akcali, K.C. 2007. Cloning and expression profile of Flt3 gene during progenitor cell-dependent liver regeneration. Journal of Gastroenterology and Hepatology, 22(12): 2181-2188.

7. Bartholomew, A., Sturgeon, C., Siatskas, M., Ferrer, K., McIntosh, K., Patil, S. Hardy, W., Devine, S., Ucker, D., Deans, R., Moseley, A. \& Hoffman R. 2002. Mesenchymal stem cells suppress lymphocyte proliferation in vitro and prolong skin graft survival in vivo. Experimental Hematology, 30(1): 42-8.

8. Bussolati, B., Tetta, C. \& Camussi, G. 2008. Contribution of stem cells to kidney repair. American Journal of Nephrology, 28(5): 813-822.

9. Campbell, J.S., Riehle, K.J., Brooling, J.T., Bauer, R.L., Mitchell, C. \& Fausto, N. 2006. Proinflammatory cytokine production in liver regeneration is Myd88-dependent, but independent of $\mathrm{Cd} 14, \mathrm{Tl} 2$, and Tlr4. The Journal of Immunology, 176(4): 2522-2528.

10. Cornell, R.P. 1985. Gut-derived endotoxin elicits hepatotrophic factor secretion for liver regeneration. American Journal of Physiology-Regulatory, Integrative and Comparative Physiology, 249(5): R551-R562.

11. Cornell, R.P., Liljequist, B.L. \& Bartizal, K.F. 1990. Depressed liver regeneration after partial hepatectomy of germ-free, athymic and lipopolysaccharide-resistant mice. Hepatology, 11: 916-922.

12. da Silva Meirelles, L., Caplan, A.I. \& Nardi, N.B. 2008. Stem Cells In search of the in vivo identity of mesenchymal stem cells. Stem Cells, 26(9): 2287-2299.

13. Fausto, N., Campbell, J.S. \& Riehle, K.J. 2006. Liver regeneration. Hepatology, 43: 45-53.

\section{Acknowledgement}

This work was supported by the Scientific and Technological Research Council of Turkey (TUBITAK) grants SBAG105S393 to KCA and SBAG106S102, SBAG108S316 to IG.

14. Friedenstein, A.J., Chailakhyan, R.K. \& Latisinik, N.V. 1970. Cell Tissue Kinet The development of fibroblast colonies in monolayer cultures of guinea-pig bone marrow and spleen cells. Cell and Tissue Kinetics, 3(4): 393-403.

15. Gursel, M., Gursel, I., Mostowski, H.S. \& Klinman, D.M. 2006. CXCL16 influences the nature and specificity of CpG-induced immune activation. The Journal of Immunology, 177: 1575- 80.

16. Higgins, G.M. \& Anderson, R.M. 1931. Experimental pathology of the liver. I. Restoration of the white rats following partial surgical removal. Archives Pathology, 12: 186-202.

17. Hofstetter, C.P., Schwarz, E.J., Hess, D., Widenfalk, J., El Manira, A., Prockop, D.J. \& Olson, L. 2002. Marrow stromal cells form guiding strands in the injured spinal cord and promote recovery. Proceedings of the National Academy of Sciences of the United States of America, 99: 2199-04.

18. Horwitz, E.M., Prockop, D.J., Fitzpatrick, L.A., Koo, W.W., Gordon, P.L., Neel, M., Sussman, M., Orchard, P., Marx, J.C. \& Pyeritz, R.E. 1999. Transplantability and therapeutic effects of bone marrow-derived mesenchymal cells in children with osteogenesis imperfecta. Nature Medicine, 5(3): 309-13.

19. Hritz, I., Velayudham, A., Dolganiuc, A., Kodys, K., Mandrekar, P., Kurt-Jones, E. \& Szabo, G. 2008. Bone marrow-derived immune cells mediate sensitization to liver injury in a myeloid differentiation factor 88dependent fashion. Hepatology, 48(4): 1342-1347.

20. Hubert, F.-X., Voisine, C., Louvet, C., Heslan, J.-M., Ouabed, A., Heslan, M. \& Josien, R. 2006. Differential pattern recognition receptor expression but stereotyped responsiveness in rat spleen dendritic cell subsets. The Journal of Immunology, 177: 1007-1016.

21. Inoue, S., Popp, F.C., Koehl, G.E., Piso, P., Schlitt, H.J., Geissler, E.K. \& Dahlke, M.H. 2006. Immunomodulatory Effects of Mesenchymal Stem Cells in a Rat Organ Transplant Model. Transplantation, 81:1589-95.

22. Koç, O.N., Gerson, S.L., Cooper, B.W., Dyhouse, S.M., Haynesworth, S.E., Caplan, A.I. \& Lazarus, H.M. 2000. Rapid hematopoietic recovery after coinfusion of autologous-blood stem cells and culture-expanded marrow mesenchymal stem cells in advanced breast cancer patients receiving high-dose chemotherapy. Journal of Clinical Oncology, 18(2): 307-307.

23. Kopen, G.C., Prockop, D.J. \& Phinney, D.G. 1999. Marrow stromal cells migrate throughout forebrain and cerebellum, and they differentiate into astrocytes after injection into neonatal mouse brains. Proceedings of the National Academy of Sciences of the United States of America, 96: 10711-10716. 
24. Kumagai, Y., Takeuchi, O. \& Akira, S. 2008. Pathogen recognition by innate receptors. Journal of Infection and Chemotherapy, 14(2): 86-92.

25. Kuo, T.K., Hung, S.P., Chuang, C.H., Chen, C.T., Shih, Y.R.V., Fang, S.C.Y., Yang, V.W. \& Lee, O.K. 2008. Stem cell therapy for liver disease: parameters governing the success of using bone marrow mesenchymal stem cells. Gastroenterology, 134(7): 2111-2121.

26. Lee, R.H., Kim, B., Choi, I., Kim, H., Choi, H.S., Suh, K., Bae, Y.C. \& Jung, J.S. 2004. Characterization and expression analysis of mesenchymal stem cells from human bone marrow and adipose tissue. Cellular Physiology and Biochemistry, 14(4-6): 311-324.

27. Mackay, A., Beck, S., Jaiswal, R., Douglas, R., Mosca, J., Moorman, M., Simonetti, D., Craig, S. \& Marshak, D. 1999. Multilineage potential of adult human mesenchymal stem cells. Science, 284(5411): 143-147.

28. Mangi, A.A., Noiseux, N., Kong, D., He, H., Rezvani, M., Ingwall, J.S. \& Dzau, V.J. 2003. Mesenchymal stem cells modified with Akt prevent remodeling and restore performance of infarcted hearts. Nature Medicine, 9: 11951201.

29. Matty, M.A. 2008. Treatment of acute lung injury: Clinical and experimental studies. Proceedings of the American Thoracic Society, 5(3): 297-299.

30. Minguell, J.J., Erices, A. \& Conget, P. 2001. Mesenchymal stem cells. Experimental Biology and Medicine, 226(6): 507-520.

31. Najimi, M. \& Sokal, E. 2005. Liver cell transplant. Minevra Pediatrica, 57: 243-57.

32. Orlic, D., Kajstura, J., Chimenti, S., Jakoniuk, I., Anderson, S.M., Li, B. Pickel, J., McKay, R., Nadal-Ginard, B., Bodine, D.M., Leri, A. \& Anversa P. 2001. Bone marrow cells regenerate infarcted myocardium. Nature, 410(6829): 701-705.

33. Pevsner-Fischer, M., Morad, V., Cohen-Sfady, M., Rousso-Noori, L., Zanin-Zhorov, A., Cohen, S., Cohen, I.R. \& Zipori, D. 2007. Toll-like receptors and their ligands control mesenchymal stem cell functions. Blood, 109: 1422-32.

34. Petite, H., Viateau, V., Bensaid, W., Meunier, A., de Pollak, C., Bourguignon, M., Oudina, K., Sedel, L. \& Guillemin, G. 2000. Tissue-engineered bone regeneration. Nature Biotechnology, 18(9): 959-63.

35. Phillippe, A.L., Compard, D., Smets, F., Najimi, M. \& Sokal E.M. 2008. Stem cells for liver tissue repair: Current knowledge and perspectives. World Journal of Gastroenterology, 14: 864-75.

36. Popp, F.C., Slowik, P., Eggenhofer, E., Renner, P., Lang, S.A., Stoeltzing, O., Geissler, E.K., Piso, P., Schlitt, H.J. \& Dahlke, M.H. 2007. No contribution of multipotent mesenchymal stromal cells to liver regeneration in a rat model of prolonged hepatic injury. Stem Cells, 25(3): 639645.
37. Rasmusson, I. 2006. Immune modulation by mesenchymal stem cells. Experimental cell research, 312(12): 2169-79.

38. Seki, E., Tsutsui, H., Iimuro, Y., Naka, T., Son, G., Akira, S., Kishimoto, T., Nakanishi, K. \& Fujimoto, J. 2005. Contribution of Toll-like receptor/myeloid differentiation factor 88 signaling to murine liver regeneration. Hepatology, 41(3): 443-450.

39. Shiratori, Y., Hongo, S., Hikiba, Y., Ohmura, K., Nagura, T., Okano, K.i., Kamii, K., Tanaka, T., Komatsu, Y. \& Ochiai, T. 1996. Role of macrophages in regeneration of liver. Digestive Diseases and Sciences, 41(10): 1939-1946.

40. Stagg, J. 2006. Immune regulation by mesenchymal stem cells: two sides to the coin. Tissue Antigens, 69: 1-9.

41. Starzl, T.E., Marchioro, T.L., Von Kaulla, K.N., Hermann, G., Brittain, R.S. \& Waddell, W.R. 1963. Homotransplantation of the liver in humans. Surgery, Gynecology \& Obstetrics, 117: 659-676.

42. Stéphenne, X., Najimi, M., Sibille, C., Nassogne, M.C., Smets, F. \& Sokal, E.M. 2006. Sustained engraftment and tissue enzyme activity after liver cell transplantation for argininosuccinate lyase deficiency. Gastroenterology, 130: 1317-1323.

43. Takeshita, F., Gursel. I., Ishii, K.J., Suzuki, K., Gursel, M. \& Klinman, D.M. 2004. Signal transduction pathways mediated by the interaction of CpG DNA with Toll-like receptor 9. In Seminars in Immunology, 16(1):17-22.

44. Tokcaer-Keskin, Z., Akar, A.R., Ayaloglu-Butun, F., Terzioglu-Kara, E., Durdu, S., Ozyurda, U., Uğur, M. \& Akcali, K.C. 2009. Timing of induction of cardiomyocyte differentiation for in vitro cultured mesenchymal stem cells: a perspective for emergencies. Canadian Journal of Physiology and Pharmacology, 87(2):143-50.

45. Tokcaer-Keskin, Z., Dikmen, Z.G., Ayaloglu-Butun, F., Gultekin, S., Gryaznov, S.M. \& Akcali, K.C. 2010. The Effect of Telomerase Template Antagonist GRN163L on Bone-Marrow-Derived Rat Mesenchymal Stem Cells is Reversible and Associated with Altered Expression of Cyclin d1, cdk4 and cdk6. Stem Cell Reviews and Reports, 6(2): 224-33.

46. Tomchuck, S.L., Zwezdaryk, K.J., Coffelt, S.B., Waterman, R.S., Danka, E.S. \& Scandurro, A.B. 2008. Toll-like receptors on human mesenchymal stem cells drive their migration and immunomodulating responses. Stem Cells, 26: 99-107.

47. Verfaillie, C.M., Pera, M.F. \& Lansdorp, P.M. 2002. Stem cells: hype and reality. Hematology / the Education Program of the American Society of Hematology: 369-391.

48. Watanabe, A., Hashmi, A., Gomes, D.A., Town, T., Badou, A., Flavell, R.A. \& Mehal, W.Z. 2007. Apoptotic hepatocyte DNA inhibits hepatic stellate cell chemotaxis via toll-like receptor 9. Hepatology, 46(5): 1509-1518.

49. Zhao, Q., Ren, H., Zhu, D. \& Han, Z. 2008. Stem/progenitor cells in liver injury repair and regeneration. Biology of the Cell, 101(10): 557-571. 